\title{
Mistagogia e o Magistério Católico recente: uma nova perspectiva na teologia moral
}

\author{
Mistagogy and recent Catholic Teaching: \\ A new perspective in Moral Theology
}

Sérgio Gonçalves Mendes

\section{Resumo}

A teologia moral desde o Concílio Vaticano II tem encontrado uma lenta e frutuosa renovação. O diálogo entre a teologia moral e a mistagogia apresentase como um campo promissor pela possibilidade de superação de um discurso excessivamente racionalista. O próprio magistério católico começa a dar cada vez mais espaço a um novo modo de se tratar a moralidade, nutrindo-a com as características da mistagogia tais como o emprego frequente das Sagradas Escrituras, o vínculo com os sacramentos e o mergulho no mistério salvífico de Deus. Os três últimos pontífices, em particular, acolheram essa forma tão nova e tão antiga de se fazer teologia.

Palavras-chave: Mistagogia. Moral Sexual. Magistério. Mistério. Teologia da ordem.

\section{Abstract}

Moral theology since Vatican II has found a slow and fruitful renewal. The dialogue between moral theology and mystagogy is presented as a promising field for the possibility of overcoming an overly rationalist discourse. The very Catholic teaching begins to give more space to a new way of treating morality, nourishing it with the mystagogy features such as the frequent use 
of the Holy Scriptures, the link with the sacraments and the dip in the salvific mystery of God. The last three pontiffs in particular welcomed this way, so new and so old, of doing theology.

Keywords: Mystagogy. Sexual Moral. Catholic Teaching. Mystery. Order Theology.

\section{Introdução}

A teologia moral católica encontra-se na pós-modernidade com o grande desafio de fazer-se ouvir. Essa demanda implica não apenas em uma mudança de linguagem, mas na própria forma de construir-se o discurso moral. É nesse propósito que a mistagogia apresenta-se como uma alternativa não apenas viável, mas muito promissora. As iniciativas nesse campo já se espalharam pelas várias instâncias do magistério e dão mostras de uma lenta e profunda mudança de paradigma teológico, superando os limites da teologia da ordem que marcou profundamente a história da moral católica até os nossos dias.

A perspectiva que se descortina é a de uma teologia moral cada vez mais ciosa de seu telos soteriológico.

\section{Mistagogia e ética cristã}

Da Idade Média até o período anterior ao Concílio Vaticano II, os termos "mistagogia" e "mistério" perderam a riqueza de significados que possuíam na Patrística. É a partir dos estudos de Odo Casel, ${ }^{1}$ da encíclica Mediator Dei de Pio XII e do Concílio Vaticano II que o termo mistério voltou à riqueza de significados da Patrística.

\subsection{O conceito de mistagogia}

O termo "mistério" no contexto patrístico significava, entre outras coisas: a salvação realizada por Deus Pai em Cristo, o culto cristão, os sacramentos, as verdades da fé (doutrina), os ritos do AT e NT, e o próprio Deus. Ao longo da história da Igreja esse termo passou a designar basicamente os sacramentos

${ }^{1}$ Cf. CASEL, O. El misterio del culto cristiano. San Sebastián: Dinor, 1953. 
e a doutrina da fé (arcanos). ${ }^{2}$ Tanto na encíclica Mediator Dei quanto na constituição conciliar Sacrosanctum Concilium resgata-se o sentido amplo de "mistério" como o plano histórico salvífico de Deus, manifestado na história do povo de Israel, chegado ao ápice na vida, morte, ressurreição de Jesus (mistério pascal), e sua atualização litúrgica, especialmente nos sacramentos da Igreja.

Contudo, essa compreensão de mistério seria insuficiente se fosse compreendida apenas como um conteúdo gnosiológico a ser compreendido e aceito. O termo mistério no contexto da fé cristã não se refere primeiramente a um conteúdo doutrinário, mas à ação salvífica contínua que Deus Pai realiza na história através de Cristo, na força do Espírito Santo. Por essa razão, não é possível a plena compreensão do significado desse termo utilizado pelos cristãos fora da experiência pessoal e comunitária do próprio Deus.

Já o termo mistagogia, que ficou praticamente esquecido ao longo da história da Igreja, tinha vários significados no período patrístico. ${ }^{3}$ Em síntese, mistagogia significava um método para interpretar a liturgia da iniciação cristã de tal modo que os vários ritos estivessem em relação com os eventos de salvação descritos pela Sagrada Escritura, ${ }^{4}$ daí o seu caráter eminentemente pedagógico-soteriológico. Para realizar a mistagogia os Padres valiam-se da tipologia bíblica, das metáforas e das comparações, a fim de aprofundarem o sentido das palavras, gestos, símbolos e orações da liturgia cristã.

Embora a mistagogia fosse destinada principalmente àqueles que desejavam aderir à fé encetando o caminho de conversão da iniciação cristã, não tardou a tornar-se um meio para aprofundar e renovar a fé daqueles que já haviam sido iniciados.

\subsection{A relação entre mistagogia e ética cristã}

No contexto patrístico não há dúvida acerca da intrínseca relação entre mistagogia e ética uma vez que o propósito de introdução ao mistério salvífico

\footnotetext{
${ }^{2}$ Cf. NEUNHEUSER, B. “Misterio”. In: SARTORE, D.; TRIACCA, A. M. Nuevo diccionario de liturgia. Vol. II. 2a ed. Madrid: Paulinas, 1987, pp. 1321-1342; CASEL, O. El misterio del culto cristiano, pp. 43-58.

${ }^{3}$ T. Federici apresenta mais de 30 significados para o termo mistagogia. Cf. FEDERICI, T. "La mistagogia della Chiesa". In: ANCILLI, E. Mistagogia e direzione spirituale. Roma: Pontificio Istituto di spiritualita del Teresianum; Milão: Ed. O.R., 1985, pp. 194-196.

${ }^{4}$ Cf. MAZZA, E. La mistagogia: Le catechesi liturgiche della fine del quarto secolo e il loro metodo. 2a ed. Roma: C.L.V.- Edizioni Liturgiche, 1996, p. 16.
} 
de Deus implica necessariamente em tornar-nos portadores da salvação para o mundo através de um agir ético. ${ }^{5}$

De modo eloquente P. Sorci expressa esse vínculo entre mistagogia e ética:

Según el NT y según la mistagogía de los padres, [la moral y espiritualidad cristiana] consiste en realizar en la vida diaria la muerte y resurrección de Cristo, que se ha realizado en ellos sacramentalmente en la inmersión y emersión bautismal, y de la que ellos se alimentan en el convite pascual renunciando cada día al pecado para vivir en novedad y libertad (Rom 6,3-11); haciendo morir en sí mismos cuanto pertenece todavía al mundo cerrado e inclinado sobre sí mismo y sobre el propio pasado (fornicación, falsedad, apetito desordenado, idolatría, ira, malignidad) y buscando las cosas de arriba (Col 3,1-9), los cielos nuevos y la tierra nueva que Dios prepara para ellos, no sin ellos (2 Pe 3,13; Ap 21,1); renovándose continuamente en la justicia y en la santidad; revistiéndose de los sentimientos de misericordia, bondad, humildad, mansedumbre, paciencia: los sentimientos del hombre nuevo, Cristo, a cuya imagen deben configurarse cada vez más (Ef 4,24; Col 3,10-12); guardando celosamente la libertad con que él los ha hecho libres $(\mathrm{Gal} 5,1){ }^{6}$

Vê-se, assim, que o objetivo da mistagogia ao debruçar-se, entre outras realidades, sobre o culto cristão (sacramentos) é conduzir a que a própria vida seja um culto a Deus ${ }^{7}$ à semelhança do próprio Cristo. Daí que a própria mistagogia pode, atualmente, ser compreendida como explicitação da dimensão mistérico-litúrgica da vida cristã (práxis).

Por fim, se partimos do pressuposto de que a mistagogia é a introdução ao mistério salvífico de Deus que continua a realizar-se na história, e se consideramos ainda que a manifestação dessa salvação de Deus em Cristo se fez pela completa doação de sua vida aos demais, e, por fim, se consideramos que o Batismo é a marca de nossa inserção completa (corpo, alma, espírito, biografia, sonhos, desejos, etc.) na vida, morte e ressurreição de Cristo, logo, a mistagogia é também a explicitação da ação do Espírito Santo em nós, a configurar-nos paulatinamente a Cristo a

\footnotetext{
${ }^{5}$ Cf. MAZZA, E. op. cit., p. 151; FEDERICI, T. "La mistagogia della Chiesa". In: ANCILLI, E. Mistagogia e direzione spirituale, p. 187.

${ }^{6}$ Cf. SORCI, P. "Misterio Pascual”. In: SARTORE, D.; TRIACCA, A. M. Nuevo diccionario de liturgia, vol. II, p. 1363.

${ }^{7}$ Cf. Rm 12,1; F1 3,3.
} 


\section{partir do Batismo e a fazer-nos participar de sua missão salvífica através da concretude de nossas ações no mundo.}

\section{O magistério e a "teologia da ordem"}

Por "teologia da ordem" queremos significar basicamente uma compreensão racionalista, de forte herança estóica, ${ }^{9}$ que afirma a existência de uma ordem natural de todas as coisas segundo leis estabelecidas por Deus. ${ }^{10}$ São precursores dessa compreensão da moralidade Santo Agostinho ${ }^{11}$ e São Tomás

\footnotetext{
${ }^{8}$ A expressão não é nossa, mas de J. B. Libânio. Cf. LIBÂNIO, J. B.; MURAD, A. Introdução à teologia: perfil, enfoques, tarefas. 6a ed. São Paulo: Loyola, 2007, p. 151. Ainda que em sentido um pouco distinto, a teologia da ordem tem precursores na antiguidade pagã, para a qual a ordem do mundo é a ordem segundo os deuses, e o homem não deve alterá-la. Cf. TENACE, M. Dire l'uomo: dall'immagine di Dio alla somiglianza. La salvezza come divinizzazione. Roma: Lipa Srl, 1997, p. 25.

${ }^{9} \mathrm{Cf}$. ROMO, W. "Credibilidad de la enseñanza de la Iglesia sobre la sexualidad". Teología y Vida 45 (2004), pp. 382-383; MAHONEY, J. The making of Moral Theology: A Study of the Roman Catholic Tradition. Oxford / London: Oxford University Press, 1989, pp. 76-77; ELDERS, L. J. The ethics of St. Thomas Aquinas: Hapiness, Natural Law and The Virtues. Frankfurt am Main: Peter Lang, 2005, pp. 17-18. Esse padre verbita situa brevemente a influência do estoicismo na concepção tomásica de "lei natural".

${ }^{10}$ Essa visão de uma ordem estabelecida por Deus encontra apoio em determinados textos bíblicos como $\mathrm{Sb} 8,1$; e também em escritos do primeiro século do cristianismo. Cf. MAHONEY, J. The making of Moral Theology, pp. 72-115. Nesse livro o jesuíta J. Mahoney lista entre os expoentes da teologia do ordenamento divino Athenágoras, Justino, Tertuliano e Agostinho. É também nesse horizonte da teologia da ordem que frequentemente se trata da "lei natural”. Cf. PINCKAERS, S. Les sources de la morale chrétienne: sa méthode, son contenu, son histoire. 4a ed. Paris: Editions du Cerf, 2007, pp. 295-301. Esse padre belga da Ordem dos Pregadores fala inclusive da influência do nominalismo para a compreensão católica da "lei natural". Dentre os diversos exemplos da teologia da ordem: cf. PIO XI, PP. "Carta Encíclica Casti Connubii". Vaticano: Libreria Editrice Vaticana, 1930, n. 9, 11; PAULO VI, PP. "Carta Encíclica Humanae Vitae". Vaticano: Libreria Editrice Vaticana, 1968, n. 10, 11, 13; JOÃO PAULO II, PP. "Exortação apostólica Familiaris Consortio". Vaticano: Copyright - Libreria Editrice Vaticana, 1981, n. 20, 34.

${ }^{11}$ Santo Agostinho, por exemplo, chega a afirmar: "Pecado es un hecho, dicho o deseo contra la ley eterna. A su vez, la ley eterna es la razón o voluntad divina que manda conservar el orden natural y prohíbe alterarlo. Es preciso investigar, pues, cuál es el orden natural en el hombre. El hombre consta de alma y cuerpo, como también el animal. Nadie duda de que, por el orden de sus naturalezas, hay que anteponer el alma al cuerpo. Pero en el alma del hombre está presente la razón, de la que carece el animal. Por tanto, como el alma se antepone al cuerpo, así la razón de la misma alma se antepone por ley de la naturaleza a sus restantes partes, que poseen también las bestias". Cf. AUGUSTÍN, S. "Réplica a Fausto, el Maniqueo", XXII, 27. Disponível em: <http:// www.augustinus.it/spagnolo/contro_fausto/index2.htm>. Acesso em 4 de junho de 2015.
} 
de Aquino. ${ }^{12}$ Mas também contribuíram para a teologia da ordem a oposição que os antigos faziam entre "teologia natural" (ou teodiceia) $)^{13}$ e "teologia sobrenatural". A primeira restrita ao contexto filosófico e marcadamente racionalista, e a segunda relativa ao contexto propriamente teológico em que predomina a revelação bíblica.

No contexto da moral cristã, a teologia da ordem conduz a certa heteronomia, em que o "inferior" deve submeter-se ao "superior", e assim respectivamente, o corpo à alma, as emoções à razão, corpo e alma a Deus, o mundo temporal ao eterno. ${ }^{14}$

Embora reconheçamos que a teologia da ordem talvez tenha sido muito adequada ao contexto em que surgiu, especialmente pelo aprofundamento da dogmática católica face aos embates com as mais diversas heresias e, posteriormente, ao difícil contexto da quebra da unidade e hegemonia católicas na passagem à Idade Moderna, passando pela oposição à ameaça comunista no século $\mathrm{XX},{ }^{15}$ há que se reconhecer que a pós-modernidade oferece agora novos e profundos desafios para a acolhida de um discurso da fé marcadamente racionalista. De fato, a pós-modernidade, caracterizase, entre outras coisas, pela rejeição dos discursos universalistas e uniformizadores que se opõem às aspirações de todo o mundo dos desejos, da afetividade e da valorização do pequeno mundo do cotidiano e das diferenças culturais; ${ }^{16}$ pela apologia da diferença e pelo concomitante rechaço à lógica da Mesmidade, da identidade fixa e da objetividade da verdade; pela limitação da religião ao foro interno da subjetividade; e, enfim, pela defesa de um relato niilista que anuncia a agonia do sujeito todo-poderoso ou pelo menos a efemeridade dos processos de construção da identidade pessoal. ${ }^{17}$

\footnotetext{
${ }^{12}$ Ao tratar, por exemplo da lei natural, diz: "La promulgación de la ley natural consiste en el hecho mismo de que Dios la implantó en las mentes de los hombres para que así la pudieran conocer naturalmente". Cf. TOMÁS DE AQUINO. Suma de Teología. 2a ed. Madrid: Biblioteca de Autores Cristianos, 1989, Ia 2ae, q. 90, art. 4, p. 708.

${ }^{13}$ Cf. SESBOÜÉ, B.; THEOBALD, C. História dos dogmas: A palavra da salvação. Vol. 4. São Paulo: Loyola, 2006, pp. 173-174. Nesta seção o título por si já denuncia uma tensão: "Teologia natural e revelação sobrenatural”. Cf. também GONZÁLEZ, A. L. Teología natural. 6a ed. Pamplona: Ediciones Universidad de Navarra, 2008, pp. 20-21.

${ }^{14} \mathrm{Cf}$. MAHONEY, J. The making of Moral Theology, p. 75.

${ }^{15} \mathrm{Cf}$. MAHONEY, J. op. cit., p. 81.

${ }^{16}$ Cf. OLIVEIRA, M. A. Ética e racionalidade moderna. $3^{\text {a }}$ ed. São Paulo: Loyola, 2002, p. 33.

${ }^{17}$ BAUMAN, Z. O mal-estar da pós-modernidade. Rio de Janeiro: Zahar, 1998, p. 155.
} 
Ora nesse contexto pós-moderno a teologia da ordem apresenta-se como um discurso de pouca audiência. Mas isso só deveria nos preocupar se esse fosse o único discurso possível. E a partir das pistas dadas pelo ConcílioVaticano II com relação à "volta às fontes"18 da fé é-nos possível reconhecer alguns limites da teologia da ordem: ela se constroi basicamente à margem da História da Salvação ao não considerar os mistérios da Encarnação, da Redenção, do horizonte escatológico e da creatio continua; tampouco ela valoriza suficientemente o mistério trinitário, privilegiando a figura criadora do Pai em detrimento das figuras do Filho e, sobretudo, do Espírito Santo. No fundo o desafio é grande porque a teologia da ordem se caracteriza por uma perspectiva atemporal, substantiva (essências metafísicas) e estática; ao passo que a História da Salvação por uma perspectiva histórica, verbal (Deus age, manifesta-se, move, toca, etc.) e dinâmica.

No entanto, apesar de todos os limites da teologia da ordem há que se reconhecer seu valor e até sua necessidade histórica. Ao mesmo tempo, cabe reconhecer igualmente que o magistério católico mais recente já se apercebeu da necessidade de orientar o discurso católico sobre a moralidade para uma nova direção. E alegra-nos detectar o progressivo resgate da mistagogia nesse intento, como passaremos agora a demonstrar.

\section{O magistério recente e o resgate da mistagogia}

Muitos são os documentos emanados das mais diversas instâncias da Cúria Romana, das Conferências Episcopais e do próprio Concílio Vaticano II que sinalizam para o resgate da compreensão patrística de mistério e mistagogia. ${ }^{19}$ No entanto, por força de brevidade nos ateremos basicamente aos pontificados dos três últimos papas, sem a pretensão de uma exaustiva análise de todas as possíveis referências. Importa-nos ilustrar apenas algumas importantes contribuições desses pontífices no campo da Moral Sexual, justamente um dos campos mais sujeitos à teologia da ordem.

\footnotetext{
${ }^{18}$ Cf. LIBÂNIO, J. B. Concílio Vaticano II: Em busca de uma primeira compreensão. São Paulo: Loyola, 2005, p. 208.

${ }^{19}$ São exemplos significativos a Constituição conciliar Sacrosanctum Concilium; o Ritual da Iniciação Cristã de Adultos; o Diretório Geral para a Catequese (1997); o Catecismo da Igreja Católica; o Documento Conclusivo da V Conferência Geral do Episcopado Latino-Americano e do Caribe (Documento de Aparecida).
} 


\subsection{João Paulo II}

Em 1981, o papa João Paulo II publicou a Exortação Apostólica Familiaris Consortio. Nela o matrimônio é apresentado como mistério e relacionado ao mistério da Igreja e aos mistérios do Senhor. ${ }^{20}$ É significativo que o pontífice, ao tratar do tema da gradualidade da conversão, quase defina o que seja a mistagogia:

É, por isso, necessário um caminho pedagógico de crescimento, a fim de que os fiéis, as famílias e os povos, antes, a própria civilização, daquilo que já receberam do Mistério de Cristo, possam ser conduzidos pacientemente mais além, atingindo um conhecimento mais rico e uma integração mais plena deste mistério na sua vida. ${ }^{21}$

Neste documento a argumentação apoia-se não raras vezes em uma soteriologia inspiradora, desenvolvida através de inúmeros temas teológicos tais como o conteúdo da Revelação, a Aliança de Deus com a humanidade, o amor de Deus, a salvação realizada em Jesus, a missão eclesial de salvação, a santificação. ${ }^{22} \mathrm{O}$ documento inova ao unir a Moral Sexual à soteriologia. No entanto, há que se reconhecer que isso não implicou em nenhum questionamento ao núcleo rígido da Moral Sexual que lhe antecedera.

Em 1994, João Paulo II publicou a Carta às Famílias Gratissimam Sane. Nela há uma riqueza de referências aos mistérios de Cristo e da Eucaristia, ${ }^{23}$ à economia da salvação, ${ }^{24} \mathrm{e}$, imitando as catequeses mistagógicas dos Padres da Igreja, vale-se do rito do matrimônio como fonte da teologia matrimonial. ${ }^{25}$

\subsection{Bento XVI}

Em 2005, o papa Bento XVI publicou a Carta Encíclica Deus Caritas est. Nela o pontífice defende a intrínseca relação entre Ética e Liturgia:

${ }^{20}$ Cf. Exortação Apostólica Familiaris Consortio, n. 16; 49; 56.

${ }^{21}$ Cf. Exortação Apostólica Familiaris Consortio, n. 9.

${ }^{22}$ Cf. Exortação Apostólica Familiaris Consortio, n. 12, 13, 15, 49, 56.

${ }^{23}$ Cf. JOÃO PAULO II, PP. "Carta às famílias Gratissimam Sane”. Vaticano: Copyright Libreria Editrice Vaticana, 1994, n. 2, 9, 16, 18,19, 20, 21.

${ }^{24}$ Cf. Carta às Famílias Gratissimam Sane, n. 2, 4, 9, 11, 13, 15, 16, 18, 19, 20, 21, 22, 23.

${ }^{25}$ Cf. Carta às Famílias Gratissimam Sane, n. 4, 10, 11, 16. 
A Eucaristia arrasta-nos no ato oblativo de Jesus. Não é só de modo estático que recebemos o Logos encarnado, mas ficamos envolvidos na dinâmica da sua doação. A imagem do matrimônio entre Deus e Israel torna-se realidade de um modo anteriormente inconcebível: o que era um estar na presença de Deus torna-se agora, através da participação na doação de Jesus, comunhão no seu corpo e sangue, torna-se união. ${ }^{26}$

As expressões "arrasta-nos", "ficamos envolvidos na dinâmica", "participação" é fruto da ação do "Logos encarnado". O movimento ético da "doação de si" acontece a partir da "participação na doação de Jesus", logo não se trata de uma ética de imitação extrínseca, mas de um dinamismo da própria experiência litúrgica com Cristo. É ele em pessoa o fundamento da eticidade cristã, o que resgata a compreensão da íntrinseca união entre culto e ética defendida pela Patrística. Não surpreende que o papa então conclua:

[...] fé, culto e ethos compenetram-se mutuamente como uma única realidade que se configura no encontro com a agape de Deus. Aqui, a habitual contraposição entre culto e ética simplesmente desaparece. No próprio "culto", na comunhão eucarística, está contido o ser amado e o amar, por sua vez, os outros. Uma Eucaristia que não se traduza em amor concretamente vivido, é em si mesma fragmentária. Por outro lado - como adiante havemos de considerar de modo mais detalhado - o "mandamento" do amor só se torna possível porque não é mera exigência: o amor pode ser "mandado", porque antes nos é dado. ${ }^{27}$

Em 2007, o papa Bento XVI, através da Exortação Apostólica Póssinodal Sacramentum Caritatis alude explicitamente à mistagogia no n. 64 e já a partir do título da seção: "Catequese mistagógica". Aqui o pontífice defende a necessidade de uma "educação da fé eucarística" que "predisponha os fiéis a viverem pessoalmente o que se celebra". Tal educação seria factível através de uma "catequese de caráter mistagógico, que leve os fiéis a penetrarem

\footnotetext{
${ }^{26}$ Cf. BENTO XVI, PP. "Carta Encíclica Deus caritas est". Vaticano: Libreria Editrice Vaticana, 2005, n. 13.

${ }^{27}$ Ibid., n. 14. No n. 17 o papa volta a explicitar ainda o papel da liturgia: "Na liturgia da Igreja, na sua oração, na comunidade viva dos crentes, nós experimentamos o amor de Deus, sentimos a sua presença e aprendemos deste modo também a reconhecê-la na nossa vida cotidiana. [...] Ele ama-nos, faz-nos ver e experimentar o seu amor, e desta 'antecipação' de Deus pode, como resposta, despontar também em nós o amor”. Cf. também o n. 34.
} 
cada vez mais nos mistérios que são celebrados". Isso não se oporia à eficácia pedagógica que a própria participação em uma "Eucaristia bem celebrada" oferece. O papa conclui oferecendo uma pista do percurso a se fazer:

[...] quem introduz nos mistérios é primariamente a testemunha; depois, este encontro aprofunda-se, sem dúvida, na catequese e encontra a sua fonte e ápice na celebração da Eucaristia. ${ }^{28}$

E ele acrescenta que esse itinerário mistagógico constitui-se de três elementos básicos: 1) interpretar os ritos à luz dos acontecimentos salvíficos;2) introduzir no sentido dos sinais contidos nos ritos; 3) mostrar o significado dos ritos para a vida cristã em todas as suas dimensões: trabalho e compromisso, pensamentos e afetos, atividade e repouso. Nesse tríplice objetivo pode-se notar uma síntese do modelo patrístico da mistagogia.

\subsection{Francisco}

Em 2013, o papa Francisco publicou sua primeira encíclica, a Lumen Fidei. Nela destaca-se o claro intento de resgatar outra linguagem para falar até mesmo da verdade da fé cristã:

Se o amor tem necessidade da verdade, também a verdade precisa do amor; amor e verdade não se podem separar. Sem o amor, a verdade torna-se fria, impessoal, gravosa para a vida concreta da pessoa. A verdade que buscamos, a verdade que dá significado aos nossos passos, ilumina-nos quando somos tocados pelo amor. Quem ama, compreende que o amor é experiência da verdade, compreende que é precisamente ele que abre os nossos olhos para verem a realidade inteira, de maneira nova, em união com a pessoa amada. Neste sentido, escreveu São Gregório Magno que o próprio amor é um conhecimento, traz consigo uma lógica nova. Trata-se de um modo relacional de olhar o mundo, que se torna conhecimento partilhado, visão na visão do outro e visão comum sobre todas as coisas. ${ }^{29}$

${ }^{28}$ Cf. BENTO XVI, PP. Exortação Apostólica Pós-sinodal Sacramentum Caritatis. Vaticano: Libreria Editrice Vaticana, 2007, n. 64.

${ }^{29}$ Cf. FRANCISCO, PP. "Carta Encíclica Lumen Fidei”. Vaticano: Libreria Editrice Vaticana, 2013, n. 27. 
Difícil não ver nessa abordagem da verdade uma diferença significativa com relação a João Paulo II. ${ }^{30}$

Na Lumen Fidei o papa Francisco faz inúmeras referências ao mistério de Deus ${ }^{31}$ e à História da Salvação. ${ }^{32}$ É digna de nota sua compreensão do papel da teologia apresentada justamente no contexto do mistério de Deus que se dá a conhecer:

[...] a teologia é impossível sem a fé e pertence ao próprio movimento da fé, que procura a compreensão mais profunda da autorrevelação de Deus, culminada no Mistério de Cristo. A primeira consequência é que, na teologia, não se verifica apenas um esforço da razão para perscrutar e conhecer, como nas ciências experimentais. Deus não pode ser reduzido a objeto; Ele é Sujeito que Se dá a conhecer e manifesta na relação pessoa a pessoa. A fé reta orienta a razão para se abrir à luz que vem de Deus, a fim de que ela, guiada pelo amor à verdade, possa conhecer Deus de forma mais profunda. Os grandes doutores e teólogos medievais declararam que a teologia, enquanto ciência da fé, é uma participação no conhecimento que Deus tem de Si mesmo. Por isso, a teologia não é apenas palavra sobre Deus, mas, antes de tudo, acolhimento e busca de uma compreensão mais profunda da palavra que Deus nos dirige: palavra que Deus pronuncia sobre Si mesmo, porque é um diálogo eterno de comunhão, no âmbito do qual é admitido o homem. Assim, é própria da teologia a humildade, que se deixa "tocar" por Deus, reconhece os seus limites face ao Mistério e se encoraja a explorar, com a disciplina própria da razão, as riquezas insondáveis deste Mistério. ${ }^{33}$

\footnotetext{
${ }^{30}$ De fato, na abertura da Carta Encíclica Veritatis Splendor afirma-se: "O esplendor da verdade brilha em todas as obras do Criador, particularmente no homem criado à imagem e semelhança de Deus (cf. Gn 1, 26): a verdade ilumina a inteligência e modela a liberdade do homem, que, deste modo, é levado a conhecer e a amar o Senhor. Por isso, reza o salmista: 'Fazei brilhar sobre nós, Senhor, a luz da vossa face"”. Cf. JOÃO PAULO II, PP. Carta Encíclica Veritatis Splendor. Vaticano: Librerira Editrice Vaticana, 1993. Nota-se aqui que a verdade parece anteceder o amor. E de fato é isso que acaba por acontecer na Carta às Famílias Gratissimam Sane, quando, além de insistir na objetividade da verdade, o papa repete 5 vezes a expressão 'verdade e amor' (n. 5, 8, 10, 11, 16) e apenas uma vez a expressão 'amor e verdade' (n. 4). Daí não causar espanto que nas Bodas de Caná o papa apresente Jesus como 'arauto da verdade divina sobre o matrimônio' (n. 18).

${ }^{31}$ Cf. Carta Encíclica Lumen Fidei, n. 13, 15, 31, 35, 36, 40, 42, 44, 45, 47, $52,57$.

${ }^{32}$ Cf. Carta Encíclica Lumen Fidei, n. 14; 20; 35; 44; 46; 50; 54; 59.

${ }^{33}$ Cf. Carta Encíclica Lumen Fidei, n. 36.
} 
Aqui o pontífice reúne novamente a teologia à experiência do mistério de Deus, tão cara à mistagogia patrística.

Em 2013, o papa Francisco, em sua Exortação Apostólica Evangelii Gaudium, retoma a mesma dinâmica de várias referências ao mistério de Deus $^{34}$ e à História da Salvação, ${ }^{35}$ mas interessa-nos sobremaneira sua reflexão sobre a mistagogia:

Outra característica da catequese, que se desenvolveu nas últimas décadas, é a iniciação mistagógica, que significa essencialmente duas coisas: a necessária progressividade da experiência formativa na qual intervém toda a comunidade e uma renovada valorização dos sinais litúrgicos da iniciação cristã. Muitos manuais e planificações ainda não se deixaram interpelar pela necessidade duma renovação mistagógica, que poderia assumir formas muito diferentes de acordo com o discernimento de cada comunidade educativa. $\mathrm{O}$ encontro catequético é um anúncio da Palavra e está centrado nela, mas precisa sempre duma ambientação adequada e duma motivação atraente, do uso de símbolos eloquentes, da sua inserção num amplo processo de crescimento e da integração de todas as dimensões da pessoa num caminho comunitário de escuta e resposta. ${ }^{36}$

Trata-se de uma explícita valorização da mistagogia. O que é bem coerente não apenas com os documentos desse pontífice, mas também com suas manifestações públicas, geralmente carregadas de gestos e palavras que esbanjam o cuidado mistagógico.

Neste ano, o papa Francisco publicou a Exortação pós-sinodal Amoris Laetitia na qual ele corajosamente une o mistério de Deus à questão do gradativo acesso à verdade:

Recordando que o tempo é superior ao espaço, quero reiterar que nem todas as discussões doutrinais, morais ou pastorais devem ser resolvidas através de intervenções magisteriais. Naturalmente, na Igreja, é necessária uma unidade de doutrina e práxis, mas isto não impede que existam maneiras diferentes

\footnotetext{
${ }^{34}$ Cf. FRANCISCO, PP. "Exortação Apostólica Evangelii Gaudium". Vaticano: Libreria Editrice Vaticana, 2013, n. 26, 111 ("mistério da Igreja"); 118, 254, 287 ("mistério [pascal] de Cristo"); 119, 141, 288 (mistério [do amor] de Deus); 171 (mistério da vida); 178 ("mistério da Trindade"); 285 (mistério salvífico); 285 ("mistérios do Evangelho").

${ }^{35}$ Ibid., n. 30; 36; 110; 112; 113; 120; 128; 137; 151; 164; 165; 181; 187; 193; 197; 233; 264; $285 ; 287$.

${ }^{36}$ Ibid., n. 166.
} 
de interpretar alguns aspectos da doutrina ou algumas consequências que decorrem dela. Assim há de acontecer até que o Espírito nos conduza à verdade completa (cf. Jo 16,13), isto é, quando nos introduzir perfeitamente no mistério de Cristo e pudermos ver tudo com o seu olhar. ${ }^{37}$

É importante notar que a progressividade do caminho de apropriação da verdade é afirmado como ação pedagógica do Espírito. Curiosamente o Magistério deixa de ocupar o primeiro lugar, como naqueles documentos marcados fortemente pela teologia da ordem. É ainda digno de nota o fato de o pontífice dedicar todo o primeiro capítulo desta carta a meditações bíblicas sobre a família. Aí se vê claramente o uso intencional do ponto de partida de toda mistagogia. A verdade da doutrina não se entende sem o mergulho no mistério salvífico de Deus. A encíclica inteira é repleta de meditações profundamente mistagógicas. ${ }^{38}$

\section{Conclusão}

Evidencia-se, pois, que especialmente a partir do Concílio Vaticano II, o discurso teológico sobre a Moral Cristã resgatou vários elementos próprios da mistagogia patrística tais como a centralidade da História da Salvação, os mistérios da vida de Cristo, o uso cuidadoso e frequente das Escrituras, a preocupação de abrir os olhos e ouvidos da assembleia cristã à manifestação presente da graça de Deus.

Ainda que esse precioso e promissor resgate não tenha ainda alcançado mudanças significativas na compreensão dos temas mais polêmicos da moral, não deixa de ser uma esperança de que as possíveis mudanças serão acompanhadas de uma fundamentação muito mais próxima àquela das fontes primeiras da Tradição cristã, e por isso mesmo, mais capaz de convencer não apenas a razão, mas também de mover os corações.

Logo, a mistagogia não é uma alternativa estratégica para melhor realizar a divulgação da doutrina cristã. Mas uma oportunidade de resgatar a experiência mais elementar da identidade cristã: a experiência do mistério de Deus revelado no encontro com Jesus de Nazaré que se faz presente na assembleia dos fieis reunidos para a oração, na proclamação da Palavra, na

${ }^{37}$ Cf. FRANCISCO, PP. Exortação pós-sinodal Amoris Laetitia. Vaticano: Libreria Editrice Vaticana, 2016, n. 3.

${ }^{38}$ Cf. Exortação pós-sinodal Amoris Laetitia, n. 73, 74, capítulo IV. 
pessoa dos ministros e especialmente nos sacramentos, destacando-se de modo eminente a Eucaristia.

Os pontífices, bem como várias instâncias do magistério universal, estão lentamente oferecendo aos fieis um dizer teológico cada vez mais inspirado e inspirador. É motivo de gratidão perceber que essa mudança não é fruto de cálculos humanos a estancar a evasão de fieis ou a promover o seu incremento numérico, mas, sobretudo, da acolhida da ação misteriosa do Espírito que nada mais deseja que conduzir-nos ao mergulho na intimidade da comunhão trinitária, à salvação.

\section{Referências bibliográficas}

AUGUSTÍN, S. "Réplica a Fausto, el Maniqueo". Disponível em: $<$ http:// www.augustinus.it/spagnolo/contro_fausto/index $2 . h t m>$. Acesso em 4 de junho de 2015.

BAUMAN, Z. O mal-estar da pós-modernidade. Rio de Janeiro: Zahar, 1998.

BENTO XVI, PP. Exortação Apostólica Pós-sinodal Sacramentum Caritatis. Vaticano: Libreria Editrice Vaticana, 2007.

BENTO XVI, PP. Carta Encíclica Deus caritas est. Vaticano: Libreria Editrice Vaticana, 2005. Disponível em: <http://w2.vatican.va/content/benedict$\mathrm{xvi} / \mathrm{pt} /$ encyclicals/documents/hf_ben-xvi_enc_20051225_deus-caritasest.html>. Acesso em 8 de novembro de 2016.

CASEL, O. El misterio del culto cristiano. San Sebastián: Dinor, 1953.

ELDERS, L. J. The Ethics of St. Thomas Aquinas: Hapiness, Natural Law and The Virtues. Frankfurt am Main: Peter Lang, 2005.

FEDERICI, T. "La mistagogia della Chiesa". In: ANCILLI, E. (Dir.). Mistagogia e direzione spirituale. Roma: Pontificio Istituto di spiritualita del Teresianum; Milão: Ed. O.R., 1985, pp. 43-58 (Collana della "Rivista di vita spirituale", n. 18).

FRANCISCO, PP. "Carta Encíclica Lumen Fidei”. Vaticano: Libreria Editrice Vaticana, 2013. Disponível em: < http://w2.vatican.va/content/francesco/ pt/encyclicals/documents/papa-francesco_20130629_enciclica-lumenfidei.html $>$. Acesso em 10 de junho de 2016.

FRANCISCO, PP. "Exortação Apostólica Evangelii Gaudium". Vaticano: Libreria Editrice Vaticana, 2013. Disponível em: < https://w2.vatican. 
$\mathrm{va} /$ content/francesco/pt/apost_exhortations/documents/papa-francesco esortazione-ap_20131124_evangelii-gaudium.html >. Acesso em 10 de junho de 2016.

FRANCISCO, PP. "Exortação pós-sinodal Amoris Laetitia". Vaticano: Libreria Editrice Vaticana, 2016. Disponível em: < https://w2.vatican. $\mathrm{va} /$ content/francesco/pt/apost_exhortations/documents/papa-francesco esortazione-ap_20160319_amoris-laetitia.html >. Acesso em 10 de junho de 2016.

GONZÁLEZ, Á. L. "Teología natural”. 6a ed. Pamplona: Ediciones Universidad de Navarra, 2008.

JOÃO PAULO II, PP. "Exortação apostólica Familiaris Consortio".

Vaticano: Copyright - Libreria Editrice Vaticana, 1981. Disponível em: < http://w2.vatican.va/content/john-paul-ii/pt/apost_exhortations/ documents/hf_jp-ii_exh_19811122_familiaris-consortio.html $>$. Acesso em 10 de junho de 2016.

JOÃO PAULO II, PP. "Carta às famílias Gratissimam Sane". Vaticano: Copyright - Libreria Editrice Vaticana, 1994. Disponível em: < https:// w2.vatican.va/content/john-paul-ii/pt/letters/1994/documents/hf_jp-ii_ let_02021994_families.html>. Acesso em 10 de junho de 2016.

JOÃO PAULO II, PP. “Carta encíclica Veritatis splendor”. Vaticano: Libreria Editrice Vaticana, 1993. Disponível em: < http://w2.vatican.va/content/ john-paul-ii/pt/encyclicals/documents/hf_jp-ii_enc_06081993_veritatissplendor.html $>$. Acesso em 8 de novembro de 2016.

LIBÂNIO, J. B. Concílio Vaticano II: em busca de uma primeira compreensão. São Paulo: Loyola, 2005.

LIBÂNIO, J. B.; MURAD, A. Introdução à teologia: perfil, enfoques, tarefas. 6a ed. São Paulo: Loyola, 2007.

MAHONEY, J. The making of Moral Theology: A Study of the Roman Catholic Tradition. Oxford / London: Oxford University Press, 1989.

MAZZA, E. La mistagogia: Le catechesi liturgiche della fine del quarto secolo e il loro metodo. 2a ed. Roma: C.L.V.- Edizioni Liturgiche, 1996.

NEUNHEUSER, B. "Misterio". In: SARTORE, D.; TRIACCA, A. M. (Dir.). Nuevo diccionario de liturgia. vol. II. 2a ed. Madrid: Paulinas, 1987, pp. 1321-1342. 
OLIVEIRA, M. A. Ética e racionalidade moderna. $3^{\mathrm{a}}$ ed. São Paulo: Loyola, 2002.

PAULO VI, PP. "Carta encíclica Humanae Vitae". Vaticano: Libreria Editrice Vaticana,1968. Disponível em: <http://www.vatican.va/holy_father/ paul_vi/encyclicals/documents/hf_p-vi_enc_25071968_humanae-vitae po.html $>$. Acesso em 22 de julho de 2013.

PINCKAERS, S. Le sources de la morale chrétienne: sa méthode, son contenu, son histoire. 4a ed. Paris: Editions du Cerf, 2007.

PIO XI, PP. "Carta Encíclica Casti Connubii”. Vaticano: Libreria Editrice Vaticana, 1930. Disponível em: <http://w2.vatican.va/content/pius-xi/ es/encyclicals/documents/hf_p-xi_enc_19301231_casti-connubii.html>. Acesso em 10 junho de 2016.

ROMO, W. "Credibilidad de la enseñanza de la Iglesia sobre la sexualidad". Teología y Vida 45 (2004), pp. 366-410.

SESBOÜÉ, B.; THEOBALD, C. História dos dogmas: A palavra da salvação. Vol. 4. São Paulo: Loyola, 2006.

TENACE, M. Dire l'uomo: dall'immagine di Dio alla somiglianza. La salvezza come divinizzazione. Roma: Lipa Srl, 1997 (Dire l'uomo, vol. II).

TOMÁS DE AQUINO. Suma de Teología. 2a ed. Madrid: Biblioteca de Autores Cristianos, 1989 (5 vol.).

\section{Sérgio Gonçalves Mendes}

Doutor em Teologia pela Pontifícia Universidade Católica do Rio de Janeiro Professor de Cultura Religiosa na Pontifícia Universidade Católica do Rio de Janeiro Rio de Janeiro / RJ - Brasil E-mail: sergiomendes2008@gmail.com

Recebido em: 15/06/2016

Aprovado em: 04/10/2016 